\title{
Explaining job polarisation in Spain from a task perspective
}

\author{
Raquel Sebastian $^{1}$ (D)
}

Received: 28 May 2017 / Accepted: 21 April 2018 / Published online: 10 May 2018

(C) The Author(s) 2018

\begin{abstract}
This paper presents new evidence on the evolution of job polarisation in Spain between 1994 and 2014. After showing the U-shaped relationship between employment share growth and job's percentile in the wage distribution, I use the task approach to investigate the main determinants behind job polarisation. Using the European Working Condition Survey I analyse in detail the task content of the jobs which display the most significant employment changes. I show that changes in employment shares are negatively related to the initial level of routine. I then explore the impact of computerisation on routine task inputs and I find that the routine measure is negatively related to computerisation. Finally, by using information on past jobs, I provide evidence on the displacement of middle-paid workers. Results suggest that they did not predominantly relocate their labour supply to bottom-paid occupations: while non-graduate middle workers move towards bottom occupations, graduate middle employees shift towards top occupations. This fact suggests that supply-side changes are important factors in explaining the expansion at the lower and upper tail of the employment distribution.
\end{abstract}

Keywords Job polarisation · Structural change · Routine employment · Occupational mobility

JEL Classification $\mathrm{J} 21 \cdot \mathrm{J} 24 \cdot \mathrm{R} 23 \cdot \mathrm{R} 12$

$\triangle$ Raquel Sebastian

raquel.sebastian@usal.es

1 Despacho 113, Facultad de Derecho, University of Salamanca, Campus Miguel de Unamuno, 37007 Salamanca, Spain 


\section{Introduction}

Debate concerning the structural evolution of the division of labour and its impact on job quality has been a central theme in social sciences for the last 200 years. In the late 1990s, the idea was that technology is skill-biased, favouring high-skilled workers and substituting low-skilled workers. While skill-biased technical change is a good explanation for the increase in the upper tail distribution of the labour force composition, it cannot explain a recent phenomenon: the decline in the share of middle occupations relative to high- and low-skilled occupations. This phenomenon has been defined as "job polarisation" (Wright and Dwyer 2003; Goos and Manning 2007).

The main drivers behind job polarisation are still subject to some debate; however, the main candidate is the so-called routinisation hypothesis (Autor et al. 2003, hereafter called ALM). Due to continuously cheaper computerisation, technology replaces human labour in routine tasks. This labour-capital substitution decreases the relative demand for workers performing routine occupations, while leading to an increase in the relative demand for workers performing non-routine tasks. Since routine workers are characterised as being in the middle of the employment distribution, then the hollowing effect is explained.

The notion that middle-skill jobs have been disproportionately destroyed and that the job distribution has hollowed out in the middle has been identified as a key aspect of contemporaneous rising labour market inequality (Acemoglu and Autor 2011; Goos et al. 2009, 2014). Therefore, understanding how the employment structure evolves can advise policy makers in designing policies to best promote a sustainable economic growth. This is especially salient, given the widespread feeling of technological anxiety (Mokyr et al. 2015). Firstly, there is a need to understand whether the shrinking of middle jobs has consequences for the possibility of moving low-skilled workers up. Secondly, an accurate understanding of occupational employment is needed in order to anticipate future skills needs and job opportunities.

Despite the importance of this topic, the results of research that assess the existence and degree of job polarisation in Spain are mixed. For example, Anghel et al. (2014) conclude that the employment structure became more polarised between 1997 and 2012, while Oesch and Rodríguez-Menés (2011) and Eurofound (2015) show a pattern of progressive upgrading for the same period. Moreover, two recent studies covering Spain, based on the European Labour Force Survey, diverge in their results. Goos et al. (2009, 2014) conclude that, on average, the employment structure in Spain became more polarised between 1993 and 2006. Using the same period of analysis, Fernández-Macías (2012) conversely shows an upgrading process (high-wage occupations expanding at the expenses of low-wage jobs) and does not provide evidence of a pervasive polarisation. These five papers have relied on graphical inspection to identify the phenomenon: terciles (Goos et al. 2009, 2014; Fernández-Macías 2012), or quintiles (Eurofound 2015; and Oesch and Rodríguez-Menés 2011).

Focusing on the Spanish case, this paper makes several contributions to the understanding of the evolution of the employment and wage structure in four complementary ways. First, I shed some light on the literature on employment polarisation in Spain, providing evidence of job polarisation in our sample; between 1994 and 2014, employment share in Spain increased at the two extremes of the job wage distribution, while it 
decreased for middle-income earners. My study adds to the literature on job polarisation, offering two new ways of representing the phenomenon and enlarging the period of analysis. ${ }^{1}$ I also contribute to widening the literature on employment remuneration in line with employment trends. In the US, Autor and Dorn (2013) find a clear correspondence between employment and wages. However, the polarisation of wages does not seem to be common in Spain, as there is no evidence that changes in pay followed the same pattern as changes in occupations. This contrasts with standard labour markets models, predicting that a positive demand shock increases both employment and earnings.

Second, I made methodological progress with respect to previous studies on job polarisation and task specialisation in European countries by measuring the tasks content of occupations from a national survey data instead of relying on US sources, like in the work of Anghel et al. (2014) and Goos et al. (2014). Therefore, no assumption on task composition and the impact of technology between the two countries is needed. Moreover, the EWCS allows for time dynamics to measure routine tasks. ${ }^{2}$ Using this survey, jobs are classified as abstract, routine, and manual tasks, similar to the ALM model. This allows for examination of the association between employment changes and the task content of occupations. Therefore, I perform a shift-share analysis to evaluate the evolution of the tasks' content, exploring whether the changes of the task content of occupation are due to changes within occupations (intensive margin) or between occupations (extensive margin).

Third, unlike previous studies, I explore the relationship between computer use and routine tasks, which I define on the basis of the frequency of repetitive activities that workers are asked to perform on the job. After creating a pseudo-panel analysis, results show a negative relationship between computers and routine tasks, and a positive association between computer and abstract tasks. However no relationship is found for manual tasks. Therefore ALM predictions are satisfied for routine and abstract tasks, but not for manual tasks.

Finally, I analysed the role of job polarisation with the relocation of middle-skilled workers. To investigate this phenomenon, the main data source is integrated with two additional datasets: the European Community Household Panel (ECHP) and the European Survey of Income and Living Conditions (SILC). Taking advantage of these new databases, the analysis builds from questions on previous occupations. There are two main findings: in line with the ALM, middle-skilled workers become more mobile over time and have the highest probability levels of mobility. However, after dividing the data into graduates and non-graduates, results suggest that while non-graduate middle workers move towards bottom occupations, graduate middle employees shift towards top occupations. This fact suggests that supply-side changes are important factors in explaining the job expansion at the lower and upper tail of the employment distribution.

\footnotetext{
1 The last year of study in the paper by Anghel et al. (2014) was 2012, while in the other analyses (Eurofound 2015; Fernández-Macías 2012; Goos et al. 2009, 2014; Oesch and Rodríguez-Menés 2011) was 2008.

2 The widely used $\mathrm{O}$ *Net task database from the US has information for only one point in time, and thus, is not suitable for analysing changes over time. The EWCS has five comparable waves (1995, 2000, 2005, 2010, and 2015) that allow me to analyse changes in the task-content of occupations.
} 
The paper is organised as follows. Section 2 clarifies the main concepts and provides a review of the literature. Section 3 describes the data and methods used for analysis. Section 4 presents the evidence on labour market polarisation, on both employment and pay rules. Section 5 investigates the task content of occupations. Section 6 looks at the impact of computer adoption on tasks. Section 7 analyses the occupational mobility of middle-pay workers. Finally, Sect. 8 summarises the main conclusions of the paper and provides a guide for future research stemming from this paper's findings.

\section{Literature review}

Job polarisation refers to the relative job growth in the lower and upper tail of the wage distribution relative to the middle-wage ones. This well-known phenomenon has been found in the US (Wright and Dwyer 2003; Autor, Katz, and Kearney. 2006; Autor and Dorn 2013), the UK (Goos and Manning 2007; Salvatori 2015), Germany (Spitz-Oener 2006; Dustmann et al. 2009; Kampelmann and Rycx 2011), and Sweden (Adermon and Gustavsson 2015). With respect to Europe, results are more controversial. On the one hand, Goos et al. $(2009,2014)$ show that on average, the employment structure in Europe polarised from 1993 to 2006. On the other hand, Fernández-Macías (2012) find heterogeneous results in Western European countries and conclude that there is not a clear and universal pattern of a pervasive polarisation. ${ }^{3}$ As for Spain, conclusions also diverge between job polarisation (Anghel et al. 2014) and occupational upgrading (Oesch and Rodríguez-Menés 2011; and Eurofound 2015). ${ }^{4}$

While in the US wage polarisation has occurred hand with hand with job polarisation (Autor et al. 2006), papers based on European countries do not find the same result. Goos and Manning (2007) failed to find wage polarisation for the UK despite the strong evidence of job polarisation. Antonczyk et al. (2010) and Kampelmann and Rycx (2011) show little evidence of wage polarisation in Germany. Finally, Massari et al. (2014) study the European labour market as a whole and conclude that there is no evidence of wage polarisation. With regards to Spain specifically, there is no study exploring this phenomenon.

Different theories have tried to explain the main drivers behind polarisation. While there are some explanations based on supply mechanisms (skill composition), almost all the theoretical explanations are based on three different demand mechanisms. The first mechanism is the propensity to offshore activities, which is not the same in all occupations. According to Blinder (2009), certain jobs are potentially more vulnerable to offshoring than others. They show that production jobs are easier to reallocate in low-income countries than service jobs. In the second place, Autor and Dorn (2013) explain that wage inequality increases income in the top earners and as a consequence, increasing the demand for bottom-paid job services. It is well known that these two factors affect specific occupations. However, the economic literature

\footnotetext{
3 It should be noted, however, that the methodology used in these analyses is not exactly the same. Fernández-Macías (2012) classifies occupations in three equally-sized groups in terms of employment shares instead of using the uneven grouping followed by Goos et al. (2014). For more information refer to the recent survey by Sebastian (2017).

4 For more information on the methodological differences, see "Appendix A".
} 
concludes that these two factors play a minor role in explaining the overall evolution of the occupational employment structure as a whole (see e.g. Autor and Katz 1999; Acemoglu and Autor 2011; Michaels et al. 2014).

In contrast, the most prominent theory accounting for job polarisation is the wellknown routinisation hypothesis, called Routine Biased Technical Change (formulated by Autor et al. 2003, RBTC). In their seminal paper, ALM propose a classification of tasks along two different dimensions: routine (as opposed to non-routine) and manual (as opposed to non-manual, or also called cognitive) tasks. Routine tasks are defined as those that "require methodical repetition of an unwavering procedure" (ALM 2003: 1283). The cognitive dimension generally refers to tasks that require gathering and processing of information and problem solving (analytic), as well as those that need creativity, flexibility and communication in order to be performed (interactive).

Autor et al. (2006), and more recently Autor and Dorn (2013) reformulate the ALM model by bringing together the two routine categories. They consider a three-fold classification scheme, where tasks are classified into abstract, routine, and manual. While this new classification shared the routine definition of the ALM model, the abstract category refers to tasks requiring problem solving and managerial tasks with high cognitive demand, and the manual tasks category refers to those ones requiring physical effort and time adaptability; therefore both tasks categories are difficult to automate.

In the ALM model, the way in which occupations are affected by new technologies depends to a large extent on the tasks they perform, rather than on their skills (normally measured using educational level). ${ }^{5}$ Two hypotheses are then formulated. The first hypothesis is that since routine tasks are easy to codify, and therefore easy to replicate by machines, the ALM model predicts the progressive substitution of technology for labour in routine tasks. The second hypothesis is that abstract tasks are characterised by complex analytical thinking, flexibility, creativity, and communication tasks, among others. These types of tasks are not only difficult to be replaced by machines, but they are also complementary to computer technologies. Therefore, the ALM model predicts complementarity between technology and abstract tasks. No assumptions are made regarding manual tasks.

Goos and Manning (2007), and Autor and Dorn (2013) use the ALM model to explain the polarisation phenomenon: since routine tasks are located in the middle of the occupation distribution, and non-routine tasks at the top and at the bottom, the ALM indicates that two key effects occur: first, employment and wages in the middle of the distribution decreased. Second, employment and wages increased (or at least remain stable) in the higher and lower qualified groups. Hence, the polarisation effect of recent technical change is explained by the RBTC. In summary, the ALM model provides a strong theoretical foundation to develop a deeper understanding of how technology may be impacting the Spanish labour market.

\footnotetext{
5 Goos and Manning (2007) and Goos et al. $(2009,2014)$ also refer to this phenomenon as "routinisation".
} 


\section{Data}

Three different datasets covering the period 1994-2014 are used in the analysis. Data on the evolution of jobs and socio-demographic characteristics come from the Spanish Labour Force Survey. Data on the evolution of wages come from the Structure of Earnings Survey. Data on tasks come from the European Working Condition Survey. Below, each data set is described in detail.

\subsection{Spanish Labour Force Survey}

The primary data source used is the Spanish Labour Force Survey (Encuesta de Población Activa, EPA, in Spanish), administered by the National Institute of Statistics. The EPA is used to estimate employment and unemployment within the ILO framework and is the basic source by which researchers can construct data series on occupations.

Although the data is compiled quarterly and is available for all years since 1964, this analysis focuses on the period 1994-2014, where the second quarter of each relevant year is sampled to avoid seasonality problems. The EPA contains data on employment status, weekly hours worked, two-digit occupational level, one-digit industry level, education, region, nationality, sex, age, and the population in each cell, among others. The dataset is weighted to reflect employment in absolute numbers.

For the chosen period, I face two important reclassifications over the period of interest. First, in relation to occupations, the CNO-94 (based on ISCO-88) was replaced by the CNO-11 (based on the ISCO-08) in 2011. Second, in terms of sectors of activity, the CNAE-93 (based on the NACE.Rev.1) was replaced by the CNAE-93 (based on the NACE.Rev.2) in 2009. I convert the occupational codes from the ISCO-08 into the ISCO-88 and the industry codes from the NACE.Rev. 2 into the NACE.Rev.1 using the crosswalk made available by Goos. ${ }^{6}$

The EPA is far from ideal. The main problem is the lack of income data necessary to rank selected job cells on earnings-based quality. To overcome this problem, I merge it with the Structure of Earnings Survey.

\subsection{Structure of Earnings Survey}

The Structure of Earnings Survey (in Spanish, Encuesta de Estructura Salarial, EES) is administered by the National Institute of Statistics. The sampling takes place in two stages. First, firms are sampled randomly from the Social Security General Register of Payments records. Second, from each of the selected firms, workers are randomly selected. The survey collects detailed information on workers' wages; personal characteristics such as gender, age, educational attainment, and nationality; and job characteristics, including sector, occupation, contract and job type, firm size and ownership, and region.

\footnotetext{
${ }^{6}$ Available at: https://www.uu.nl/staff/MGoos/0.
} 
For the period under study, the survey has been carried out five times (1995, 2002, 2006, 2010, and 2014). For the 1995 ESS, not all the employed population is covered: the survey is only representative of employees working in companies of at least ten employees in the sectors $\mathrm{C}$ to $\mathrm{O}$ (excluding L) of the NACE.Rev.1 classification of economic activities. For the 2002 ESS, the 2006 ESS, the 2010 EES, and the 2014 ESS, the coverage of the survey is extended to include some non-market services (educational, health, and social services sectors).

To measure job polarisation, I use the 2002 wave rather than the other surveys, as my results remain invariant, which is preferable for two reasons. First, the 1995 EES does not include employees working in companies of at least ten workers, selfemployed workers, and public employees. Second, between 2002 ESS and 2006 EES, I rather prefer the $2002 \mathrm{ESS}$, as it is closer to the initial period. Moreover, to measure wage polarisation, all five cohorts and all wages are deflated to the year 1995 using the Consumer Price Index (CPI).

Like the EPA, there are two modifications at the occupation and industry code for the 2010 ESS and the 2014 ESS. The surveys display occupations using the CNO-11 (based on the ISCO-08) and industry using the CNAE-93 (based on NACE.Rev.2). Moreover I convert the ISCO-08 into the ISCO-08 and the NACE.Rev. 2 into the NACE.Rev.1 using the same mapper that I explained above.

\subsection{Measuring the task content of jobs}

In order to establish the task content of each job's measures, information on the activities performed by workers on the job is required. Task measures at the job level are derived from an additional source, the European Working Condition Survey (EWCS). Unlike previous studies on job polarisation in Spain (see Anghel et al. 2014 and Goos et al. 2014), this study does not rely on the US O*Net survey to derive data on job task requirements. Hence, there is no need to assume that the task composition is the same in the two countries. Moreover, there are two different features between the US $\mathrm{O}^{*}$ Net and the EWCS. Firstly, while the original purpose of the US O*Net is an administrative evaluation by Employment Services offices of the fit between workers and occupations, the EWCS is conducted for research. Secondly, differently from the US O*Net where analysts at the Department of Labor assign scores to each task according to standardised guidelines, the EWCS derive individual tasks measures. Although the EWCS presents a higher level of subjectivity, this feature has the advantage of giving a more precise idea of the tasks performed within each occupation. Autor and Handel (2013), who use a similar type of survey to derive individual task measures (the Princeton Data Improvement Initiative survey, PDII), argue that their data have a greater explanatory power for occupations and wages than those derived from the O*Net. ${ }^{7}$

The EWCS is administered by the European Foundation for the Improvement of Living and Working Conditions (Eurofound) and has become an established source

\footnotetext{
7 Previous papers that have used workers-reported information to build task measures include Spitz-Oener (2006) for Germany, Green (Green 2012) for the UK, and Autor and Handel (2013) for the US.
} 
of information about working conditions and the quality of work and employment. With six surveys (one every 5 years) having been conducted since 1990, it enables monitoring of long-term trends in working conditions in Europe. At each time point, information on employment status, working time arrangements, work organisation, learning and training, and work-life balance, among others is collected. In this research, five surveys (1995-2015) are used for analysis. The five repeated cross-sections cover 1000 in 1995, 1500 in 2000, 1017 in 2005, 1008 in 2010, and 3364 in 2015. Sampling weights adjusted for responses are used through the analysis. The analysis is restricted to individuals aged from 16 to 65 . Jobs are classified according to the ISCO-88 nomenclature at the two-digit level and NACE.Rev.1 at the one-digit level.

I follow the same framework as Autor et al. (2003), and Autor and Dorn (2013) to estimate the effects of job polarisation. This classification is based on a threedimensional typology: abstract, routine, and manual. To limit the role played by my subjective judgement, I follow the work of Autor and Handel (2013) as closely as possible, as they use variables that are most similar to those available in the EWCS. I construct the indexes for each of the three dimensions using the first component of a principal component analysis and then compute the indexes into their standardised form. ${ }^{8}$

For the abstract tasks, I retain the following items: "learning new things", "solving unforeseen problems", "complex tasks", "assessing yourself on the quality of your job", and "influence decisions that are important". 9 For the manual tasks, I resort to responses on "physical strength" (e.g. carrying or moving heavy loads), "skill or accuracy in using fingers/hands" (e.g. repetitive hand or finger movements), and "physical stamina" (e.g. painful positions at work). ${ }^{10}$ For the routine tasks, I opt for the routine activities performed within the respondents' jobs: does your main job involve (1) short repetitive tasks of less than a minute, (2) short repetitive tasks of less than $10 \mathrm{~min}$, (3) monotonous and repetitive tasks, and (4) dealing with customers. ${ }^{11}$

I created three separate standardised indices for abstract, manual, and routine job aspects using the sub-components enumerated above for each of these aspects. Given that all the sub-components are either dichotomous or ordinal, I perform a principle component analysis using a polychoric correlation matrix. The proportion of variance explained by the first component is $0.58,0.67$ and 0.68 for the abstract, manual, and routine aspects respectively (see "Appendix B" for further information).

Following Autor and Dorn (2013), I create a routine task intensity measure (RTI) to compare findings to those in the literature. This measure aims to capture how important the routine tasks are compared to tasks components of countries. Indices

\footnotetext{
8 Autor and Handel (2013) follow a principal component analysis to derive continuous job task variables taking advantage of multiple responses of items.

9 The first four items are binary questions $(1=$ yes, $2=$ no). The last question provides answers in intensity frequencies $(1=$ all of the time, $2=$ almost all of the time, $3=$ around $3 / 4$ of the time, $4=$ around half of the time, $5=$ around $1 / 4$ of the time, $6=$ almost never, $7=$ never).

10 Questions provide answers in intensity frequencies $(1=$ all of the time, $2=$ almost all of the time, $3=$ around $3 / 4$ of the time, $4=$ around half of the time, $5=$ around $1 / 4$ of the time, $6=$ almost never, $7=$ never).

11 Questions provide answers in intensity frequencies $(1=$ all of the time, $2=$ almost all of the time, $3=$ around $3 / 4$ of the time, $4=$ around half of the time, $5=$ around $1 / 4$ of the time, $6=$ almost never, $7=$ never).
} 
Table 1 Correlation between EWCS and O*Net. Sources: author's analysis from EWCS and O*Net data

\begin{tabular}{lllll}
\hline & $\begin{array}{l}\text { EWCS survey } \\
\text { abstract }\end{array}$ & $\begin{array}{l}\text { EWCS survey } \\
\text { routine }\end{array}$ & $\begin{array}{l}\text { EWCS survey } \\
\text { manual }\end{array}$ & $\begin{array}{l}\text { EWCS survey } \\
\text { RTI }\end{array}$ \\
\hline O*Net abstract & 0.762 & & & \\
O*Net routine & & 0.677 & 0.866 & \\
O*Net manual & & & 0.811 \\
O*Net RTI & & &
\end{tabular}

Correlations are computed at a two-digit occupation level

are standardised with a mean of 0 and a standard deviation of 1 . The RTI is then calculated as follows:

$$
R T I_{1994}=\ln \left(T_{1994}^{R}\right)-\ln \left(T_{1994}^{A}\right)-\ln \left(T_{1994}^{M}\right)
$$

where $T_{1994}^{R}, T_{1994}^{A}$, and $T_{1994}^{M}$ are the routine, abstract, and manual inputs in Spain in 1994. This measure is rising in the importance of routine tasks in Spain and declining in the importance of abstract and manual tasks.

Before proceeding with the analysis, Table 1 shows a correlation between the EWCS and $\mathrm{O}^{*}$ Net. ${ }^{12}$ The measures of the two surveys are positively correlated, with the RTI having the highest correlation (0.86) and routine task having the lowest correlation (0.67). The results indicate that both surveys are close enough, indicating that the EWCS is a suitable measure.

\section{The evolution of employment and wages in Spain}

\subsection{The evolution of employment}

The starting point of the analysis is to investigate the pattern of employment change in the Spanish labour market, acting as a preliminary step for the subsequent analysis. Unless otherwise noted, throughout this paper, employment is modelled by occupation (ISCO-88 at the two-digit level) and by industry (NACE.Rev.1 at the one-digit level). Employment share is computed from EPA data, while the employment ranking is based on the mean wage from the 2002 EES data. ${ }^{13}$

A common way of analysing the development of jobs is through graphical illustration. For this, the employment shares by each job are computed, along with changes over time. To avoid bias due to small jobs drive dominating results, each job is weighted by its total employment. Jobs are ranked according to their 2002 EES mean wage. ${ }^{14}$ Then, the percentage point change in employment share is plotted against the log

\footnotetext{
12 US Census 2000 codes are matched to the International Standard Classification of Occupations.

13 I merge the EPA with the EES, and two filters are applied to the final data. First, I drop the occupations where I do not have information (ISCO 11, ISCO 61 and ISCO 92.). Second, I retain only those jobs which appear in both surveys and with at least five observations. After applying both filters, I reduce the total number of jobs from 279 to 226. See "Appendix C" for details on the measures discussed in this section.

14 The shape of the graph does not change if median average earnings are used for determining job quality.
} 


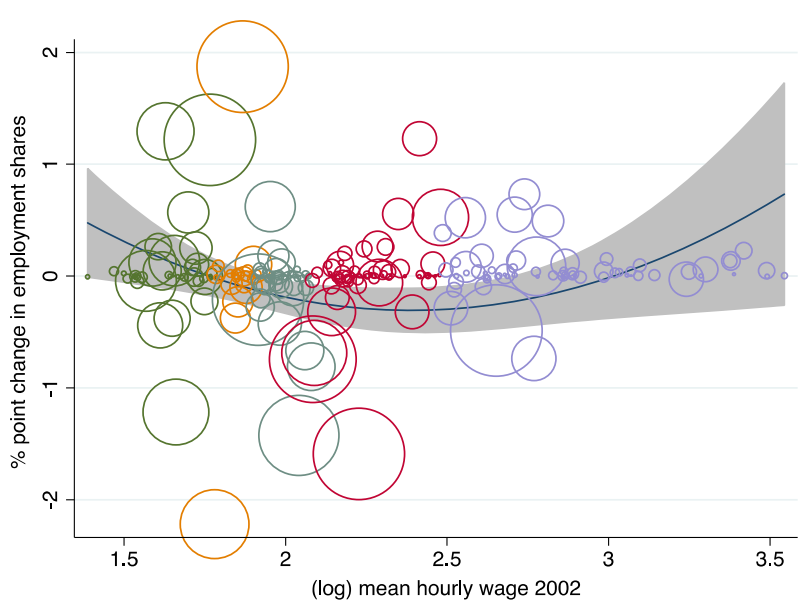

Fig. 1 Employment shares growth in Spain (1994-2014) by mean hourly wage. Notes scatter plot and quadratic prediction curve. The dimension of each circle corresponds to the number of observations within each ISCO-88 two-digit occupation and NACE.Rev.1 one-digit occupation in 1994; the grey area shows 95\% confidence interval. Employment shares are measured in terms of workers. Colours represent the quintile of each job (green, first quintile; yellow, second quintile, grey, third quintile; red, fourth quintile; and violet, fifth quintile). Sources: author's analysis from the Spanish Labour Force Survey (1994, 2014), and the Structure of Earnings Survey (2002) (color figure online)

mean hourly wage. If the structure of employment has polarised, it is expected that employment in bottom and top-paid jobs increased, while it decreased in the middle of the wage distribution.

Previous literature has represented the phenomenon using aggrupation of jobs (either quintiles or terciles), being these presentations being very sensible to the definition of jobs and to the classification of these jobs (see Sebastian 2017 for a longer explanation). In order to avoid these problems, in this research I add two new representations: the parametric graph ( Fig. 1) and the smooth regression (Fig. 2).

The first graphical method (Fig. 1) corresponds to the parametric graph. Figure 1 shows the evolution of Spanish employment between 1994 and 2014. As noted already, employment shares are measured by two-digit occupations (ISCO-88) and by one-digit sectors of activity (NACE.Rev.1). Earnings are measured by the logarithm of hourly mean in each job in 2002. The employment changes in Spain show a clear pattern of job polarisation, in which the higher and lower part of the earnings distribution increased while the middle-earnings part has shrunk. A U-shaped curve can be detected in the evolution of employment shares, when jobs are ranked according to the hourly mean wage.

Using the parametric graph, a test for job polarisation can be conducted. In order to do so, the following model of the quadratic form is estimated as proposed by Goos and Manning (2007):

$$
\Delta \log E_{j}=\beta_{0}+\beta_{1} \log \left(w_{j, t-1}\right)+\beta_{2} \log \left(w_{j, t-1}\right)^{2}
$$




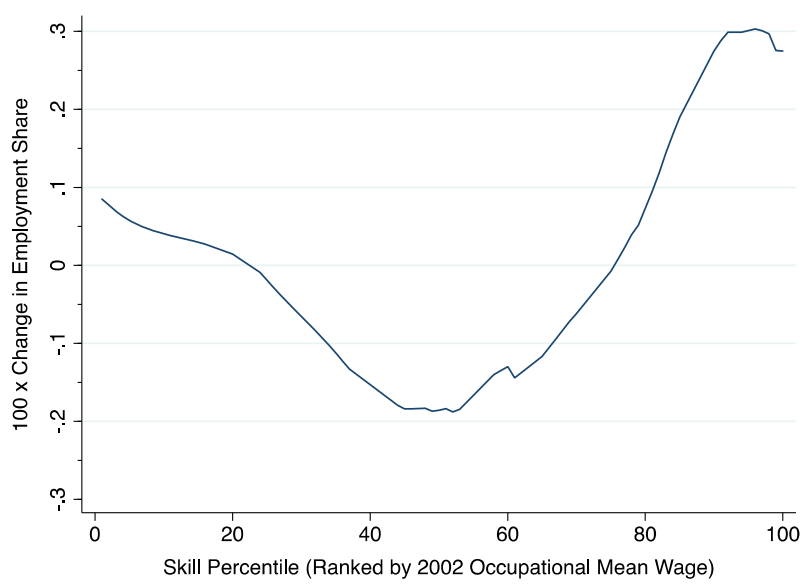

Fig. 2 Smoothed changes in Employment by wage percentile (1994, 2014). Notes the figure plots log changes in employment share by 2002 job skill percentile rank using a locally weighted smoothing regression (bandwidth 0.75 with 100 observations), where skill percentiles are measured as the employment-weighted percentile rank of a job's mean log wage in the 2002 ESS. Sources: author's analysis from the Spanish Labour Force Survey $(1994,2014)$, and the Structure of Earnings Survey (2002)

Table 2 Regressions for job polarisation. Sources: author's analysis from the Spanish Labour Force Survey (1994, 2014), and the Structure of Earnings Survey (2002)

Log change in employment share 1994-2014

(log) mean hourly wage 1994

Sq. (log) mean hourly wage 1994

$\mathrm{N}$

Adj. $\mathrm{R}^{2}$

$\mathrm{F}$
$-5.42 * * *$

(2.12)

$1.20^{* * *}$

$(0.31)$

226

0.14

7.91

Each job is weighted by the initial number of observations. Robust standard errors between parentheses, significance levels $* * * p<0.01 ; * * p<0.05 ; * p<0.10$

where $\Delta \log E_{j}$ is the change in the $\log$ employment share of job $j$ between $t-1$ and $t, \log \left(w_{j, t-1}\right)$ is the logarithm of the mean wage of job $j$ in $t-1$, and $\log \left(w_{j, t-1}\right)^{2}$ is the square of the initial mean wage. A U-shaped relationship between the employment growth and the wages implies that the quadratic term is positive.

Table 2 presents the results of the OLS regression using weekly hours worked as a measure for employment shares rather than expressing them in terms of bodies. Equation (1) is estimated by weighting each job by its initial employment share in 1994 to avoid that results are biased by compositional changes in small jobs. All regression coefficients have the expected sign and are significant at the $1 \%$ level. The results indicate that Spain was characterised by a polarisation pattern in employment growth from 1994 to 2014 . The phenomenon of job polarisation is also robust to the use of the median instead of the mean. 


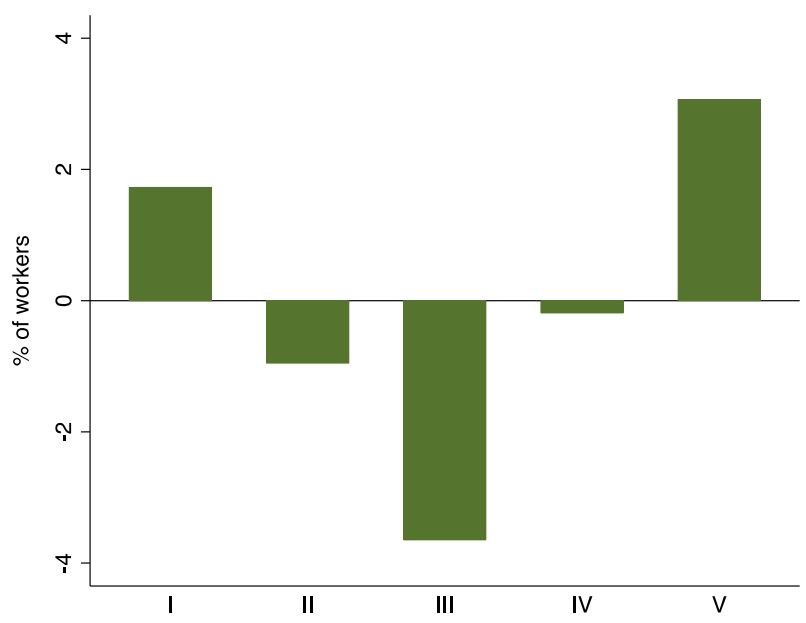

Fig. 3 Relative net employment change $(1994,2014)$ ranked by 2002 wage mean. Notes jobs wage quintiles are based on two-digit occupation and one-digit industry and on mean wages in 2002. It shows the relative net employment change quintiles (in percentage points). Sources: author's analysis from the Spanish Labour Force Survey (1994, 2014), Earnings Structure Survey (2002)

The second representation method is by defining job wage percentile. ${ }^{15}$ In this particular case, smoothing regressions are displayed rather than the actual data point (the previous case). Therefore, changes in employment share are plotted against the percentile of the initial earnings distribution. A U-shaped curve is detected and shown in Fig. 2. The main advantage of this method is that the biggest increases and losses are observable. For Spain, the biggest losses are between the $20^{\text {th }}$ and the $40^{\text {th }}$ percentile of the initial mean wage distribution. Overall, the shape of employment changes in the EPA data confirms other studies with Spanish data and suggests that job polarisation is a robust phenomenon in Spain.

Figure 3 shows the quintile plot. In this occasion, I follow the methodology applied in Europe by Fernández-Macías (2012). In Fig. 3, I plot the relative employment share by job wage quintile. Quintiles are created by ranking jobs by their initial mean wage and aggregating them into five quintiles. Each group contains the $20 \%$ of employment in the initial year. ${ }^{16}$ The resulting graph (Fig. 3) demonstrates an even clearer pattern of job polarisation. In this case, top- and bottom-income jobs grow up and there is a decline in middling jobs.

Three robustness tests for the results presented above are implemented to ensure the validity of the results. First, there are three reclassification breaks during the period. I establish three time periods due to changes in classification (1994-2008, 2008-2010, and 2010-2014). Second, the results are subjected to sensitivity testing with respects

\footnotetext{
15 This methodology has been applied by Autor and Dorn (2013).

16 It is not possible to create groups which contain exactly the same percentage of employment since occupations are defined as inseparable units.
} 
to the choice of the reference year. The 1995 EES and 2006 EES years were selected. Third, jobs are ranked by median rather than mean earnings. In all cases, graphs result are invariant, the characteristic U-shaped curve is detected in the evolution of employment shares ("Appendix D", Figs. 4, 5, 6, 7, 8). Using the database, the employment changes in Spain between 1994 and 2014 are found to be consistent with the polarisation phenomenon, where employment growth occurs for bottom- and top-paid jobs, while decreases for middling-paid jobs.

\subsection{The evolution of wages}

In this section, and after studying the evolution of employment, I study the evolution of remuneration of jobs for the period 1995-2014. ${ }^{17,18}$ It is expected that the evolution of employment and the evolution of wage level matches. As a consequence, to predict changes in wages, the same quadratic model is used to detect the U-shaped evolution of employment shares (Kampelmann and Rycx 2011). Therefore, to examine wage polarisation, the following model is estimated:

$$
\Delta \log \left(w_{j}\right)=\beta_{0}+\beta_{1} \log \left(w_{j, t-1}\right)+\beta_{2} \log \left(w_{j, t-1}\right)^{2}
$$

where $\Delta \log \left(w_{j}\right)$ is the change in the log mean wage of job $j$ between $t-1$ and $t$, $\log \left(w_{j, t-1}\right)$ is the logarithm of the mean wage of job $j$ in $t-1$, and $\log \left(w_{j, t-1}\right)^{2}$ is the square of the initial mean wage.

Table 3 reports the OLS for the wage polarisation analysis. In this report, the number of individuals within a job in 1994 weights the initial number of observations in each job. The coefficients have the expected sign, but are not significant. These findings suggest that in Spain, between 1995 and 2014, wages did not experience the same polarised pattern of employment shares.

Finally, the changes in employment share are evaluated to match changes in pay rule. To do so, the correlation coefficient is computed between the two variables $(\rho=0.06)$. The coefficient is positive but weak. Contrary to the existing literature in the US (Autor and Dorn 2013) and Germany (Kampelmann and Rycx 2011), the results suggest that the relationship between changes in employment share and changes in pay rules is almost zero in Spain.

\footnotetext{
17 In this paper, wage polarisation is understood in the following way: first jobs are ranked according to their mean hourly wage in the first year. The change in wages is measured in each occupation between the first and the last year of our period of study. If the mean wage of jobs is found to be growing at the top and bottom of the wage ranking in the first year, while the mean wage of jobs in the middle of the ranking is decreasing, this phenomenon is defined as wage polarisation.

18 During the period study I deal with two reclassifications at the occupation and industry level. The 2010 ESS and the 2014 ESS display occupations using the CNO-11 (based on the ISCO-08) and industry using the CNAE-93 (based on NACE.Rev.2). Like the EPA, I convert the ISCO-08 into the ISCO-08 and the NACE.Rev. 2 into the NACE.Rev.1.
} 
Table 3 OLS regression for wage polarisation analysis. Sources: author's analysis from the Structure of Earnings Survey (1995 and 2014)

\begin{tabular}{ll}
\hline & Change in (log) mean wage, 1995-2014 \\
\hline (log) mean hourly wage 1995 & -0.80 \\
& $(0.32)$ \\
Sq. $(\log )$ mean hourly wage 1995 & 0.35 \\
& $(0.10)$ \\
N & 160 \\
Adj. $\mathbf{R}^{2}$ & 0.03 \\
F & 3.77 \\
\hline
\end{tabular}

The initial number of observations weights each job. Robust standard errors between parentheses, significance levels $* * * p<0.01 ; * * p<0.05 ; * p<0.10$

\section{Task-based analysis}

\subsection{Employment changes and tasks intensities}

Thus far, it has been shown that there is a hollowing out of the employment distribution in Spain, while there is no evidence of wages following the same pattern. In order to better interpret the previous results, I follow a task-based approach. I use information on the activities carried out by workers on their jobs, where each worker performs different tasks with different intensities. Therefore, each job is not defined by one single task, but it can be classified as with a predominant task. To proceed with the analysis, I gather information concerning the nature of tasks performed by workers. As already explained in Sect. 3, this data comes from the European Working Survey.

Table 4 presents the pairwise correlation between the task measures and the education attainment at the two-digit ISCO-88 level and one-digit NACE.Rev.1. The correlation between the abstract dimension and the routine measure is negative, while is positive with the manual task and the education variable. The RTI is negatively correlated with the abstract dimension and positively correlated with the routine and

Table 4 Correlation among the task measures and the education variable. Sources: author's analysis from the Spanish Labour Force Survey and the European Working Condition Survey

\begin{tabular}{lrcccc}
\hline & Abstract & Routine & Manual & RTI & Education \\
\hline Abstract & 1 & & & & \\
Routine & -0.788 & 1 & & & \\
Manual & 0.532 & 0.621 & 1 & & \\
RTI & -0.853 & 0.856 & 0.755 & 1 & \\
Education & 0.743 & -0.822 & -0.798 & -0.821 & 1 \\
\hline
\end{tabular}

Correlations are computed at ISCO-88 two-digit level and NACE.Rev.1 one-digit level 
manual task. The education measure is positive correlated with the abstract dimension, while is negative with the routine and manual content.

I proceed with my analysis aggregating the 226 jobs so far considered at the ISCO88 two-digit level. This aggregation offers a clear interpretation of the tasks content of the occupations that mainly contributed to the polarisation of the employment structure.

Table 5 reports changes in employment share by major occupational groups (twodigit ISCO-88 level) and are ranked in ascending order by their mean wage in 1995. The mean level of education in 1994 (column 2) is also included. I draw on Goos et al. (2014) to classify these occupations in three major groups: the first six occupations in the bottom distribution are defined as bottom occupations, the next eight occupations as middle occupations, and the top seven occupations are labelled as top occupations. The groups include six, eight, and seven occupations respectively and they represent $35 \%, 37 \%$, and $28 \%$ of the employment distribution. ${ }^{19}$ These groups represent the theoretical classification of the RBTC model with services and elementary occupations at the bottom of the occupational distribution, productive and administrative occupations being in the middle, and professional and managerial at the top of the top of the occupational distribution. Moreover, from Table 5, it is clear that the shift of employment goes from the middle to the top: of the $7.1 \%$ of the employment shares lost in the middle, $6.8 \%$ go to the top and $0.42 \%$ to the bottom occupations.

To illustrate the richness data at the occupational level, Table 6, columns 2 to 5 present the average values of the task measures. In matching Table 5 with Table 6 , a complete picture of the task content can be formed, which determines job polarisation in Spain. In line with expectations, the RTI values are higher among clerical work, repetitive production, and monitoring. Managers and professionals instead score among the lowest.

Analysing the bottom group occupation, results indicate that half of the occupations are growing in employment share, while the other half are losing employment share. The occupations that experience the most significant employment growth represent a mixture of elementary occupations such as "Personal and protective services workers" (ISCO 51), and services such as "Sales and services elementary occupations" (ISCO 91). These findings confirm that the increase of employment at the lower tail of the wage distribution is mainly driven by a job expansion in the service sector. Moreover, these occupations score higher in the manual than in the routine dimension. This is in line with the prevailing RBTC theory that low-skilled jobs rely on manual tasks, therefore are not affected by the introduction of technology.

Concerning the middle occupations, "Office clerks" (ISCO 41), "Metal, machinery and related trades workers" (ISCO 72), and "Precision, handicraft, printing, and trades workers" (ISCO 73) are those that register the highest employment losses, scoring higher in the routine dimension than in the manual measure. Moreover, "Pre-

\footnotetext{
19 Fernández-Macías (2012) criticises this classification, arguing that a division in even groups would not lead to job polarisation in Europe. Our results remain invariant to this alternative classification. I still observe the polarisation pattern with middle-occupations exhibiting relative declining shares with respect to the top and the bottom.
} 
Table 5 Occupations, mean wage, and education. Sources: author's analysis from the Spanish Labour Force Survey $(1994,2014)$ and the Structure of Earnings Survey (1995)

\begin{tabular}{|c|c|c|c|c|}
\hline Occupation & ISCO-88 & $\begin{array}{l}\text { Mean wage in } \\
1995 \\
\text { (1) }\end{array}$ & $\begin{array}{l}\text { Mean level of } \\
\text { education } \\
\text { (2) }\end{array}$ & $\begin{array}{l}\text { Employment share } \\
\text { (1994-2014) } \\
\text { (3) }\end{array}$ \\
\hline \multicolumn{5}{|c|}{ Bottom occupations (35\%) } \\
\hline $\begin{array}{l}\text { Labourers in } \\
\text { mining } \\
\text { construction, and } \\
\text { manufacturing }\end{array}$ & 93 & 7.21 & 1.22 & -0.55 \\
\hline $\begin{array}{l}\text { Sales and services } \\
\text { elementary } \\
\text { occupations }\end{array}$ & 91 & 8.03 & 1.18 & 1.72 \\
\hline $\begin{array}{l}\text { Other craft and } \\
\text { related trades } \\
\text { workers }\end{array}$ & 74 & 8.17 & 1.18 & -1.91 \\
\hline $\begin{array}{l}\text { Personal and } \\
\text { protective } \\
\text { services workers }\end{array}$ & 51 & 8.44 & 1.51 & 2.25 \\
\hline $\begin{array}{l}\text { Models, } \\
\text { salespersons, and } \\
\text { demonstrators }\end{array}$ & 52 & 9.50 & 1.47 & -0.28 \\
\hline $\begin{array}{l}\text { Extraction and } \\
\text { building trades } \\
\text { workers }\end{array}$ & 71 & 9.65 & 1.23 & -0.81 \\
\hline $\begin{array}{l}\text { Total employment } \\
\text { share }\end{array}$ & & & & $(0.42)$ \\
\hline \multicolumn{5}{|c|}{ Middle occupations (37\%) } \\
\hline $\begin{array}{l}\text { Drivers and } \\
\text { mobile plant } \\
\text { operators }\end{array}$ & 83 & 10.10 & 1.20 & -0.68 \\
\hline $\begin{array}{l}\text { Machine operators } \\
\text { and assemblers }\end{array}$ & 82 & 10.27 & 1.29 & -0.82 \\
\hline $\begin{array}{l}\text { Precision, } \\
\text { handicraft, } \\
\text { printing, and } \\
\text { trades workers }\end{array}$ & 73 & 10.33 & 1.48 & -1.57 \\
\hline $\begin{array}{l}\text { Customer service } \\
\text { clerks }\end{array}$ & 42 & 10.96 & 2.26 & 0.54 \\
\hline $\begin{array}{l}\text { Metal, machinery, } \\
\text { and related } \\
\text { trades workers }\end{array}$ & 72 & 12.77 & 1.49 & -1.75 \\
\hline Office clerks & 41 & 13.19 & 2.33 & -2.54 \\
\hline $\begin{array}{l}\text { Life science and } \\
\text { health associate } \\
\text { professionals }\end{array}$ & 32 & 14.34 & 2.94 & 0.31 \\
\hline
\end{tabular}


Table 5 continued

\begin{tabular}{|c|c|c|c|c|}
\hline Occupation & ISCO-88 & $\begin{array}{l}\text { Mean wage in } \\
1995 \\
(1)\end{array}$ & $\begin{array}{l}\text { Mean level of } \\
\text { education } \\
(2)\end{array}$ & $\begin{array}{l}\text { Employment share } \\
\text { (1994-2014) } \\
(3)\end{array}$ \\
\hline $\begin{array}{l}\text { Stationary-plant } \\
\text { and related } \\
\text { operators }\end{array}$ & 81 & 15.33 & 1.45 & -0.59 \\
\hline $\begin{array}{l}\text { Total employment } \\
\text { share }\end{array}$ & & & & $(-7.1)$ \\
\hline \multicolumn{5}{|c|}{ Top occupations (28\%) } \\
\hline $\begin{array}{l}\text { Physical and } \\
\text { engineering } \\
\text { associate } \\
\text { professionals }\end{array}$ & 31 & 18.44 & 2.66 & 1.00 \\
\hline $\begin{array}{c}\text { Other associate } \\
\text { professionals }\end{array}$ & 34 & 18.94 & 2.39 & 2.59 \\
\hline $\begin{array}{l}\text { Other } \\
\text { professionals }\end{array}$ & 24 & 21.68 & 3.88 & 0.28 \\
\hline $\begin{array}{l}\text { Life science and } \\
\text { health } \\
\text { professionals }\end{array}$ & 22 & 22.33 & 3.91 & 0.29 \\
\hline $\begin{array}{l}\text { Physical, } \\
\text { mathematical, } \\
\text { and engineering } \\
\text { profession }\end{array}$ & 21 & 24.30 & 3.92 & 1.03 \\
\hline $\begin{array}{l}\text { Teaching } \\
\text { professionals }\end{array}$ & 23 & 25.90 & 3.89 & 0.90 \\
\hline $\begin{array}{l}\text { Corporate } \\
\text { managers }\end{array}$ & 12 & 33.10 & 2.64 & 0.59 \\
\hline $\begin{array}{l}\text { Total employment } \\
\text { share }\end{array}$ & & & & $(6.68)$ \\
\hline
\end{tabular}

Occupations are ranked in ascending order by the mean hourly wage in 1995; column 2 reports the mean of the educational attainment in 1994, based on four-values variable (elementary, basic, medium, and high); and column 3 shows the percentage point in employment share over the period 1994-2014

cision, handicraft, printing, and trades workers" (ISCO 82) has the highest score in RTI.

Finally, within the group of the highest paying occupations, "Other associate professionals" (ISCO 34) and "Physical, mathematical, and engineering profession" (ISCO 21) are those that experienced the most significant employment growth. Consistent with the ALM model, these seven occupations score higher on the abstract dimension than on the manual task. These occupations demand tasks such as flexibility, problem solving, creativity, and complex communication. Therefore, the likelihood of technology substituting for workers in carrying out these tasks is very limited.

Table 7 presents results OLS regressions of changes in employment share between 1994 and 2014 and the initial level of routine intensity of each occupation. As expected, I found a negative relationship between the two variables: higher routine task intensity leads to larger declines in employment occupations. 
Table 6 Tasks measures by occupations. Sources: author's analysis from the Spanish Labour Force Survey and the European Working Condition Survey

\begin{tabular}{|c|c|c|c|c|c|}
\hline Occupation & ISCO-88 & $\begin{array}{l}\text { Abstract } \\
\text { (1) }\end{array}$ & $\begin{array}{l}\text { Routine } \\
\text { (2) }\end{array}$ & $\begin{array}{l}\text { Manual } \\
\text { (3) }\end{array}$ & $\begin{array}{l}\text { RTI } \\
\text { (4) }\end{array}$ \\
\hline \multicolumn{6}{|c|}{ Bottom occupations (35\%) } \\
\hline $\begin{array}{l}\text { Labourers in } \\
\text { mining } \\
\text { construction, } \\
\text { and manufac- } \\
\text { turing }\end{array}$ & 93 & 0.60 & 0.49 & 0.75 & 0.53 \\
\hline $\begin{array}{l}\text { Sales and } \\
\text { services } \\
\text { elementary } \\
\text { occupations }\end{array}$ & 91 & 0.52 & 0.52 & 0.76 & 0.83 \\
\hline $\begin{array}{l}\text { Other craft and } \\
\text { related trades } \\
\text { workers }\end{array}$ & 74 & 0.52 & 0.57 & 0.62 & 0.68 \\
\hline $\begin{array}{l}\text { Personal and } \\
\text { protective } \\
\text { services } \\
\text { workers }\end{array}$ & 51 & 0.55 & 0.35 & 0.67 & 0.03 \\
\hline $\begin{array}{l}\text { Models, } \\
\text { salespersons, } \\
\text { and demon- } \\
\text { strators }\end{array}$ & 52 & 0.64 & 0.66 & 0.55 & 0.43 \\
\hline $\begin{array}{l}\text { Extraction and } \\
\text { building } \\
\text { trades } \\
\text { workers }\end{array}$ & 71 & 0.52 & 0.68 & 0.63 & 0.94 \\
\hline \multicolumn{6}{|c|}{ Middle occupations (37\%) } \\
\hline $\begin{array}{l}\text { Drivers and } \\
\text { mobile plant } \\
\text { operators }\end{array}$ & 83 & 0.45 & 0.77 & 0.64 & 1.33 \\
\hline $\begin{array}{l}\text { Machine } \\
\text { operators and } \\
\text { assemblers }\end{array}$ & 82 & 0.41 & 0.78 & 0.61 & 1.41 \\
\hline $\begin{array}{l}\text { Precision, } \\
\text { handicraft, } \\
\text { printing, and } \\
\text { trades } \\
\text { workers }\end{array}$ & 73 & 0.64 & 0.65 & 0.41 & -0.01 \\
\hline $\begin{array}{l}\text { Customer } \\
\text { service clerks }\end{array}$ & 42 & 0.54 & 0.69 & 0.62 & 0.89 \\
\hline $\begin{array}{l}\text { Metal, } \\
\text { machinery, } \\
\text { and related } \\
\text { trades } \\
\text { workers }\end{array}$ & 72 & 0.66 & 0.72 & 0.65 & 0.73 \\
\hline
\end{tabular}


Table 6 continued

\begin{tabular}{|c|c|c|c|c|c|}
\hline Occupation & ISCO-88 & $\begin{array}{l}\text { Abstract } \\
\text { (1) }\end{array}$ & $\begin{array}{l}\text { Routine } \\
\text { (2) }\end{array}$ & $\begin{array}{l}\text { Manual } \\
\text { (3) }\end{array}$ & $\begin{array}{l}\text { RTI } \\
\text { (4) }\end{array}$ \\
\hline Office clerks & 41 & 0.54 & 0.53 & 0.31 & -0.43 \\
\hline $\begin{array}{l}\text { Life science } \\
\text { and health } \\
\text { associate } \\
\text { professionals }\end{array}$ & 32 & 0.67 & 0.65 & 0.53 & 0.29 \\
\hline $\begin{array}{l}\text { Stationary- } \\
\text { plant and } \\
\text { related } \\
\text { operators }\end{array}$ & 81 & 0.59 & 0.63 & 0.7 & 0.81 \\
\hline \multicolumn{6}{|c|}{ Top occupations (28\%) } \\
\hline $\begin{array}{l}\text { Physical and } \\
\text { engineering } \\
\text { associate } \\
\text { professionals }\end{array}$ & 31 & 0.65 & 0.39 & 0.42 & -0.69 \\
\hline $\begin{array}{l}\text { Other } \\
\text { associate } \\
\text { professionals }\end{array}$ & 34 & 0.69 & 0.42 & 0.29 & -1.18 \\
\hline $\begin{array}{l}\text { Other } \\
\text { professionals }\end{array}$ & 24 & 0.80 & 0.33 & 0.25 & -1.92 \\
\hline $\begin{array}{l}\text { Life science } \\
\text { and health } \\
\text { professionals }\end{array}$ & 22 & 0.74 & 0.45 & 0.43 & -0.64 \\
\hline $\begin{array}{l}\text { Physical, } \\
\text { mathemati- } \\
\text { cal, and } \\
\text { engineering } \\
\text { profession }\end{array}$ & 21 & 0.75 & 0.38 & 0.31 & -1.34 \\
\hline $\begin{array}{l}\text { Teaching } \\
\text { professionals }\end{array}$ & 23 & 0.79 & 0.38 & 0.36 & -1.21 \\
\hline $\begin{array}{l}\text { Corporate } \\
\text { managers }\end{array}$ & 12 & 0.72 & 0.33 & 0.31 & -1.48 \\
\hline
\end{tabular}

Occupations are ranked in ascending order by the mean hourly wage in 1995. Column 1 to 4 reported normalised tasks measures in 1997 ranging [0.1]

Table 7 OLS regression of changes in employment share and the initial level of routine intensity. Sources: author's analysis from the Spanish Labour Force Survey and European Working Condition Survey

\begin{tabular}{ll}
\hline & $1994-2014$ \\
\hline Routine Task Index & $-0.677^{* * *}$ \\
$R^{2}$ & $(0.120)$ \\
$N$ & 0.17 \\
\hline
\end{tabular}

The regression includes a constant. Robust standard errors between brackets. The dependent variable is measured using ISCO-88 at two-digit level and NACE.Rev.1 at one-digit level 
Table 8 Tasks shifts, intensive and extensive margin. Sources: author's analysis from the Spanish Labour Force Survey and the European Working Condition Survey

\begin{tabular}{lccr}
\hline & Abstract & Routine & Manual \\
\hline Importance 1995 & 61.40 & 56.77 & 60.83 \\
Importance 2015 & 63.98 & 61.25 & 55.15 \\
Change & 2.58 & 4.48 & -5.68 \\
Extensive margin & 1.78 & -1.69 & -1.46 \\
Intensive margin & 0.80 & 6.17 & -4.22 \\
\hline
\end{tabular}

\subsection{Task intensities over time}

Understanding the evolution of tasks measures across time allow further analysis of job polarisation. The composition of tasks constitutes a vital piece of information for testing the routinisation hypothesis. I analyse changes in the task structure of the labour market to determine if task structure relies on the changes within occupations (i.e. the intensive margin) or between occupations (i.e. the extensive margin).

Table 8 presents the importance of the tasks in 1995 and 2015, and reports the results of the shift-share analysis. The change decomposition of tasks of each occupation is as follows:

$$
\Delta T_{k}=\sum_{j} \Delta E_{j} \gamma_{j k}+\sum_{j} \Delta \gamma_{j k} E_{j}
$$

where $\Delta T_{k}$ and $\Delta E_{j}$ are the change in importance of tasks $k$ and the change in employment in occupation $j$ between 1995 and 2015, and $\gamma_{j k}$ represents the importance of task $k$ in occupation $j$. Finally, $\Delta \gamma_{j k}$ is the change in the share of task $k$ in occupations and $E_{j}$ is the average share of occupation $j$. The first term on the right-hand-side equation is the extensive margin, i.e. the task importance is held constant (and represents the average task importance across the 2 years), and time variation relies on changes across occupations. The second term is the intensive margin where occupational employment is held constant while the importance of tasks within occupations is allowed over time.

Table 8 compares the importance of the three tasks groups in 1995 and 2015 and the change between 1995 and 2015. Results indicate that manual tasks became less important in the Spanish economy, while abstract and routine tasks increased in magnitude. In the last two rows, I divide the decomposition effect into changes within occupations ("the intensive margin") and changes between occupations ("the extensive margin"). The increasing importance of the routine tasks occurs at the intensive margin, whereas abstract tasks increased in importance due to changes at the extensive margin. Therefore, while routine tasks are increasing because routine occupations are now more routinised, abstract tasks are increasing because occupations with a lower level of abstract tasks are now demanding it. The decreasing importance of manual 
tasks seems to rely mainly on the extensive margin. In other words, manual tasks have lost employment due to decreasing tasks' importance within jobs.

\section{Technological change and tasks}

The ALM model predicts that technology substitutes for labour in routine tasks but complements it in non-routine abstract tasks. No assumption is made for non-routine manual tasks. Therefore, I investigate the effect that computers have on tasks inputs. To do so, I create a pseudo-panel testing the computerisation hypothesis, with the following regression model:

$$
\bar{T}_{t j t}=\beta \bar{C}_{j t}+\sum_{t=1}^{T-1} \theta_{t}+\delta_{j}+\bar{\varepsilon}_{j t}
$$

where $\bar{T}_{t j t}$ is the task measure in either: (1) abstract, (2) routine, and (3) manual tasks at the job level $j$ at time $t$. The main regressor of interest, $\overline{\mathrm{C}}_{\mathrm{jt}}$ is the variable capturing computer intensity in job $j$ at time $t$ (see "Appendix E" for further details on how is derived). The specification includes a set of year effects $\left(\theta_{t}\right)$ and a set of occupation effects $\left(\delta_{\mathrm{j}}\right)$. Time fixed effects are included to control for omitted variables that vary across time, but not varying across occupations. Occupations' fixed effects control for omitted variables that are not constant across occupations but which evolve over time.

Table 9 presents results of the fixed effects regressions of the initial abstract task (column 1), routine task (column 2), and manual task (column 3), and the initial level of computer use for each job. As expected, the results are in line with the ALM model: on the one hand, technology is significant and negative related with routine tasks. On the other hand, there is a positive effect between computer use and abstract task: workers in managerial, professional, and creative occupations are complements with computers. Regarding manual tasks, where the ALM does not predict any effect, there is negative a relationship between manual task and computer use. However, the manual coefficient is not significant, suggesting that the computer's substitution is higher among routine tasks.

Table 9 Impact of computer on adoption on task measures. Sources: author's analysis from the Spanish Labour Force Survey and the European Working Condition Survey

\begin{tabular}{llll}
\hline & \multicolumn{2}{l}{ Dependent variable } & Manual \\
\cline { 2 - 4 } & Abstract & Routine & -0.214 \\
\hline Computer use & $0.136^{* *}$ & $-0.321^{* * * *}$ & $(0.19)$ \\
$\mathrm{N}$ & $(0.02)$ & $(0.04)$ & 348 \\
$\mathrm{R}^{2}$ & 348 & 348 & 0.71 \\
$\mathrm{~F}$ (years dummy) & 0.88 & 0.89 & 2.98 \\
\hline
\end{tabular}

Fixed-effects estimate using ISCO-88 at two-digit level and NACE.Rev.1 at one-digit level 


\section{Occupational mobility of middle-paid workers}

The analysis has provided empirical evidence of the negative impact of computerisation on routine workers, and therefore their displacement. In this section, the analysis is completed by switching the focus to occupational mobility of middle-paid workers.

The model proposed by Autor and Dorn (2013) provides a framework in which the continuously falling price of technology induces low-skilled routine workers to relocate from routine to manual tasks, at the bottom of the employment distribution. Therefore, first, it is expected that routine workers become more mobile over time, and second, the subsequent relocation of routine workers at the bottom of the employment distribution is expected.

The main drawback of the EWCS is the lack of information on past jobs. To overcome this problem, the main source of data is merged with two additional databases: the European Community Household Panel (ECHP), and its continuation, the Survey of Income and Living Conditions (SILC). ${ }^{20}$ The ECHP and the SILC are longitudinal surveys of the employment circumstances of the European population covered from 1994 to 2000 (for the ECHP) and from 2005 to 2015 (for the SILC). At each interval, information on job characteristics and working condition is provided. Among other details, it includes information on activity and employment status, job characteristics, earnings, and education. For the analysis, individuals who are not in both years of the analysis are excluded. Due to data restrictions, I divide the period into two: from 1994 to 2000 (using the ECHP) and from 2005 to 2015 (using the SILC).

Table 10 presents the occupational mobility by educational group. In order to control for education, I create a three-level education variable ranging from 1 (low-education) to 3 (high-education), having as a result three types of workers: low-, middle-, and highskilled workers. The table shows the percentage of workers that change occupation among those with the same educational attainment. The results are divided into two periods and two sub-periods. The first period is from 1994 to 2000 and the two subperiods are: 1994-1997 (column 1) and 1997-2000 (column 2). The second period covers 2005 to 2015, where the two sub-periods are: 2005-2008 (column 4) and 2012-2015 (column 5). Column 3 and Column 6 contain mobility over time. In line with the RBTC model, middle-skilled workers are shown to become more mobile over time (5.5 and 4.1\%), against low-skilled (4.6 and 3.3\%) and high-skilled workers (2.4 and $0.90 \%$ ).

After showing that middle-skilled workers become more mobile over time, middlepaid workers are analysed to determine if they moved towards bottom- or top-paid occupations. Following the model by Autor and Dorn (2013) and later revisited by Cortes (2016), it is expected that middle workers relocate towards bottom-paid occupations, under the assumption that its relative comparative advantage is higher in manual than abstract tasks. In this paper, and differently from Schmidpeter and Winter-Ebner (2016), I only analyse downward and upward mobility and not flows into unemploy-

\footnotetext{
20 The European Community Household Panel (ECHP) covers the period 1994-2001. The Survey of Income and Living Conditions goes from 2005 to 2015.
} 
Table 10 Occupational change by educational group. Sources: author's analysis from the Spanish Labour Force Survey, the European Community Household Panel, and the Survey of Income and Living Conditions

\begin{tabular}{lllllllll}
\hline & \multicolumn{3}{l}{ Occupational change $($ ECHP) } & & \multicolumn{3}{l}{ Occupational change (SILC) } \\
\cline { 2 - 3 } & $1994-1997$ & $1997-2000$ & Mobility & & $2005-2008$ & $2012-2015$ & Mobility \\
\hline Education & $(1)$ & $(2)$ & $(3)$ & & $(4)$ & $(5)$ & $(6)$ \\
Low & 7.11 & 11.78 & 4.67 & & 8.99 & 12.38 & 3.39 \\
Medium & 9.15 & 14.68 & 5.53 & & 10.15 & 14.25 & 4.10 \\
High & 6.38 & 8.82 & 2.44 & & 7.63 & 8.53 & 0.90 \\
$\mathrm{~N}$ & 4308 & 2924 & & & 5678 & 4523 & \\
\hline
\end{tabular}

The table shows the percentage of workers that change occupation among those with the same educational attainment

ment or inactivity. The idea behind this decision is that the analysis done so far only covers workers. $^{21}$

My enquiry builds on the transition probability matrix, where each cell corresponds to the transition process of being in one job and move to another given by:

$$
p_{i j}=\operatorname{Pr}\left(X_{t}=j \mid X_{t}=i\right)
$$

The probability from Eq. 6 can be computed as expressed in Eq. (7)

$$
p_{i j}=N_{i j} / \sum_{j=1}^{n} N_{i j}
$$

where $N_{i j}$ is the total number of workers changing from job $i$ to job $j$ (the cell counts) and $\sum_{j=1}^{n} N_{i j}$ is the total number of workers in the same job (the row counts).

In Table 11, each cell corresponds to the transition probability from one occupation to another in four different periods: from 1994 to 1997, from 1997 to 2000, from 2005 to 2008 and from 2012 to 2015 . Moreover, workers are divided into graduate and non-graduate. ${ }^{22}$ Therefore, I compare the exit probabilities for each skill category of workers, middle, bottom, and top across each decade.

Two important remarks can be discerned from this table. First, middle workers have the highest probability levels of mobility. However, the mobility pattern is different when I take into account skills categories. For non-graduate workers, there is an increase in the probability of switching from middle to bottom occupations; this being more pronounced in the second decade. The picture is not the same for graduate employees in middle occupations; these workers become more likely to move up the occupational ladder to top occupations.

\footnotetext{
21 Adding unemployment and inactivity will determine if it could be that middle-workers end up outside the labour market.

22 Autor and Dorn (2009) and a much more recent paper by Lewandowski et al. (2017) document the important relationship between age and occupational mobility due to polarisation.
} 


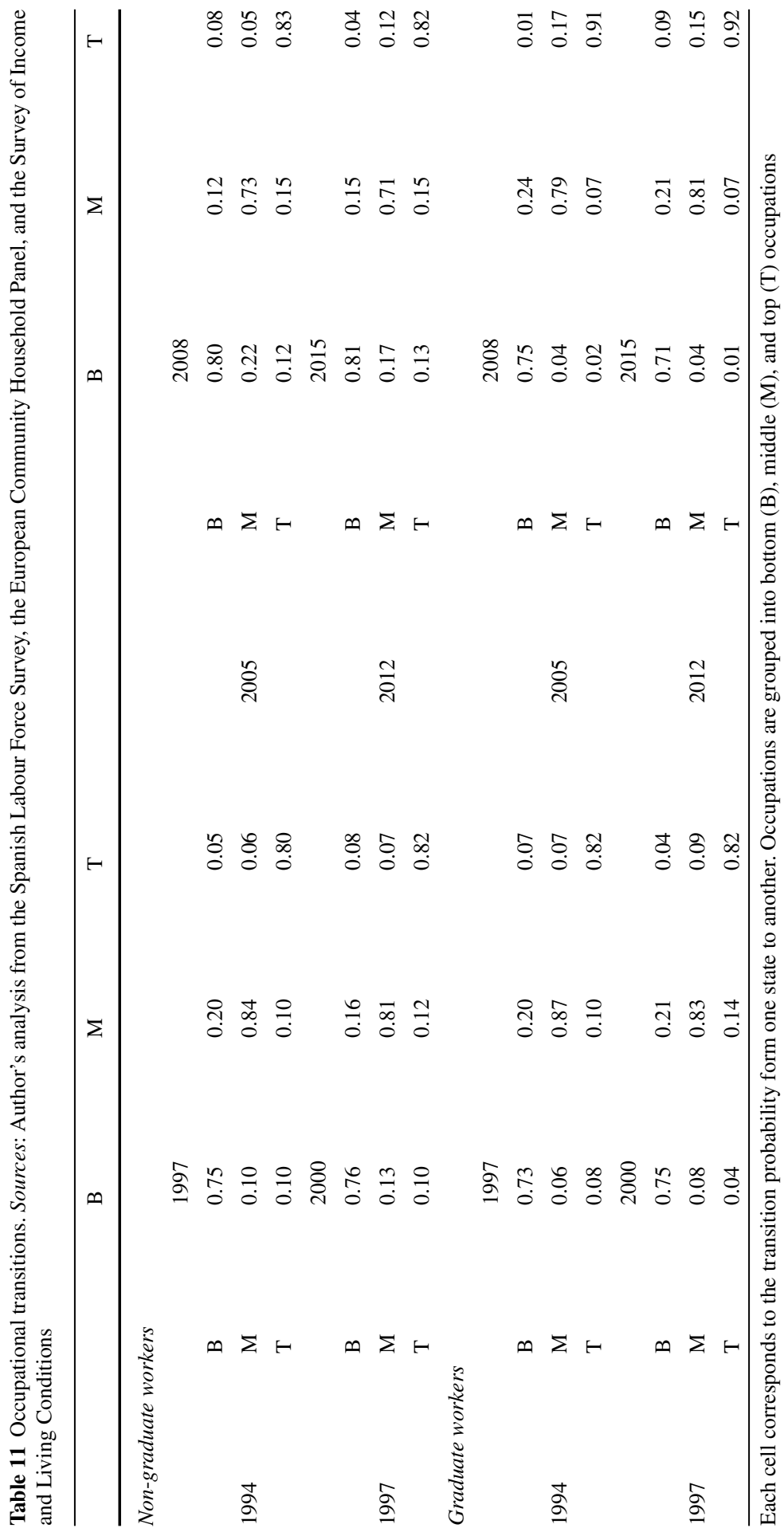


Second, the probability of moving down from top to middle occupations is higher for non-graduate employees than graduate workers, and this fact increases over time. At the same time, non-graduate workers in bottom occupations have a decline in the probability of moving to middle jobs.

In summary, the results suggest that there is a relocation of middle-skilled workers. However, different from Autor and Dorn (2013) model, only non-graduate workers move towards bottom-paid occupations. This last result raises doubts as to the leading role of technology, indicating that more needs to be done to understand the main determinants behind job polarisation. Education plays an important role in explaining the increase at the two tails of the employment distribution.

\section{Conclusions}

This paper contributes to the debate on labour market polarisation in Spain using Spanish task data to measure the job content of occupations. Through the analysis, I show graphically and empirically that employment in Spain became polarised between 1994 and 2014. However, there is no evidence of a similar trend in wages, unlike previous findings from the US. The sample suggests that jobs in bottom and top occupations increased, while employment shares decreased in the middle of the distribution.

I interpret the evolution of employment from a task-based perspective, exploring ALM model's prediction. As the theory predicts, top and bottom occupations increased the most, the former being classified as abstract tasks and the latter as manual tasks. Moreover, middle-paid occupations have lost a significant employment share and can be classified as routine. In the same line, changes in employment shares are negatively related to the initial level of routine intensity index.

To enrich the analysis and to gain a better empirical understanding, I created a pseudo-panel to evaluate the association between computer use and routine task. Results suggest a negative relationship between the impact of computerisation and routine tasks, and a positive effect with abstract tasks. No effect is found for manual tasks. This suggests that middle-paid occupations are substitutes with computer use.

Finally, the analysis focuses on the progressive substitution of technology for labour in routine tasks, and how this contributed to the employment growth at the bottom part of the occupational distribution. By merging the main database with the ECHP and SILC, the analysis exploits questions about past jobs. As the model predicts, workers in middle-paid occupations become more mobile over time and they have the highest probability levels of mobility. Moreover, after dividing the data into graduate and non-graduate workers, I find that non-graduate middle workers move towards bottom occupations, while graduate middle employees shift towards top occupations. This fact counters Autor and Dorn (2013) prediction, as they expect that middle workers relocate to bottom-paid occupations.

One important observation can be made from this last result. While employment in Spain experienced a polarising trend at the occupational level between 1994 and 2014, the transitional analysis uncovers that the probability of switching for graduate middle workers to the top of the distribution significantly accelerates during the 2000 s, coinciding with the dramatic changes in graduate labour supply. Far from suggesting 
that technology does not matter, this last result highlights that understanding the main drivers behind job polarisation is more difficult than expected. Much remains to be understood, especially when making predictions about the future of jobs.

Acknowledgements I am particularly indebted to Dr. Carlos Gradin and Enrique Fernández-Macías for their supervision while I was visiting the University of Vigo and Eurofound. I would like to thank Rafael Muñoz de Bustillo and José Ignacio Antón for helpful discussion. I am also grateful to two anonymous referees and one editor for their comments and suggestions. I acknowledge the financial support of the Eduworks Marie Curie Initial Training Network Project (PITN-GA-2013-608311) of the European Commission's 7th Framework Program. I thank participants of the AIAS lunch seminar, 2016 Barcelona GSE Summer Forum, the 2016 EALE in Ghent, and the 2016 SAEe in Bilbao for comments and useful discussions.

Open Access This article is distributed under the terms of the Creative Commons Attribution 4.0 International License (http://creativecommons.org/licenses/by/4.0/), which permits unrestricted use, distribution, and reproduction in any medium, provided you give appropriate credit to the original author(s) and the source, provide a link to the Creative Commons license, and indicate if changes were made.

\section{Appendix A: Methodology in 5 Spanish papers}

See Table 12.

\section{Appendix B: The construction of the indexes}

The procedure I have followed for constructing the indices can be summarized in a number of steps:

1. Identification of variables: I first identified the variables that could match the elements in our model.

2. Normalization of variables to a $0-1$ scale: in the original sources, the individual variables use different scales which are not directly comparable. Therefore, they had to be normalized before they could be aggregated. I opted for a normative rescaling to $0-1$, with 0 representing the lowest possible intensity of performance of the task in question, and 1 the highest possible intensity.

3. Correlation analysis: once the variables related to an individual element in my model were normalized, I proceeded to analyse the correlations between them. In principle, different variables measuring the same underlying concept should be highly correlated, although there are situations in which they may legitimately not be (for instance, when two variables measure two compensating aspects of the same underlying factor). Beside standard pairwise correlations, I computed Cronbach's Alpha to test the overall correlation of all the items used for computing a particular index, and a Principal Components Factor Analysis to evaluate the consistency of the variables and identify variables that did not fit my concept well.

4. Once I selected the variables to be combined into a single index, I proceeded to combine them, by using the first component of a Principal Component Analysis. ${ }^{23}$ Unless I had a particular reason to do otherwise, all the variables used for a particular index received the same weight.

23 The results remain invariant if I use the first component of the principal component analysis. 
Table 12 Methodology in 5 Spanish papers

\begin{tabular}{|c|c|c|c|c|c|}
\hline & $\begin{array}{l}\text { Anghel et al. } \\
(2014)\end{array}$ & $\begin{array}{l}\text { Fernández- } \\
\text { Macías } \\
(2012)\end{array}$ & $\begin{array}{l}\text { Eurofound } \\
\text { (2015) }\end{array}$ & $\begin{array}{l}\text { Goos et al. } \\
(2014)\end{array}$ & $\begin{array}{l}\text { Oesch and } \\
\text { Rodríguez- } \\
\text { Menés } \\
(2011)\end{array}$ \\
\hline Country & Spain & $\begin{array}{c}15 \text { European } \\
\text { countries } \\
\text { (Spain is } \\
\text { included) }\end{array}$ & Spain & $\begin{array}{c}16 \text { European } \\
\text { countries } \\
\text { (Spain is } \\
\text { included) }\end{array}$ & $\begin{array}{l}\text { Germany, } \\
\text { Spain, } \\
\text { Switzerland, } \\
\text { and the UK }\end{array}$ \\
\hline Years & 1997-2007 & 1995-2007 & 1994-2008 & 1993-2006 & 1990-2008 \\
\hline $\begin{array}{l}\text { Definition of } \\
\text { job }\end{array}$ & $\begin{array}{l}\text { Two digit } \\
\text { occupation }\end{array}$ & $\begin{array}{l}\text { Two digit } \\
\text { occupation } \\
\text { Two digits } \\
\text { industry }\end{array}$ & $\begin{array}{l}\text { Two digit } \\
\text { occupation } \\
\text { One digits } \\
\text { industry }\end{array}$ & $\begin{array}{l}\text { Two digit } \\
\text { occupation } \\
\text { One digits } \\
\text { industry } \\
\text { *Excluded: } \\
\text { agriculture, } \\
\text { household } \\
\text { activities, and } \\
\text { public } \\
\text { defence. }\end{array}$ & $\begin{array}{l}\text { Three digit } \\
\text { occupation }\end{array}$ \\
\hline $\begin{array}{l}\text { Definition of } \\
\text { quality }\end{array}$ & Mean salary & Median salary & Median salary & Median salary & Median salary \\
\hline Data & $\begin{array}{l}\text { EPA and ESS } \\
1995\end{array}$ & $\begin{array}{l}\text { EU-ESS } 2002 \\
\text { and EU-SILC } \\
2006\end{array}$ & $\begin{array}{l}\text { EPA, ESS } 2006 \\
\text { and SILC } \\
2006\end{array}$ & $\begin{array}{l}\text { ECHP (2004) } \\
\text { and EU-SILC } \\
(1994)\end{array}$ & $\begin{array}{l}\text { CIS } 1989 \text { and } \\
\text { 2006, and } \\
\text { Erik and } \\
\text { Wright } \\
\text { survey (1990) }\end{array}$ \\
\hline Figure & $\begin{array}{l}7 \text { occupational } \\
\text { groups }\end{array}$ & Quintiles & Quintiles & Terciles & Quintiles \\
\hline Result & $\begin{array}{l}\text { Job } \\
\text { polarisation }\end{array}$ & Job upgrading & Job upgrading & $\begin{array}{l}\text { Job } \\
\text { polarisation }\end{array}$ & Job upgrading \\
\hline
\end{tabular}

5. Finally, I proceeded to compute their average scores for all the occupation combinations at the two-digit level and sector of activity at the one-digit level. When the data source included the information at the individual worker level, I computed also the standard deviation and number of workers in the sample, for later analysis.

6. Data from the EPA on the level of employment in each job was added to the dataset holding the task indices. These employment figures were later used for weighting the indices.

\section{Appendix C: Methodology applied to measured job polarisation}

My enquiry builds on a methodology first proposed by Joseph Stiglitz for the study of occupational change in the US, later refined by Wright and Dwyer (2003). Due to its simplicity, it is subsequently applied subsequently applied to British (Goos and Manning 2007), German (Kampelmann and Rycx 2011), Swedish (Adermon and 
Gustavsson 2015) and European data (Goos et al. 2009, 2014; Fernández-Macías 2012). Three steps are usually followed.

In the first step, I define a job as a particular occupation in a particular industry. Therefore, jobs are classified into a matrix whereas the columns are economic sectors and the rows are occupations. Examples of these jobs would be managers in the agricultural sector or clerks in the construction industry. Throughout our investigation, I use two-digit International Standard Occupational Classification (ISCO-88) code and one-digit industry codes from the Classification of Economic Activities in the European Community (NACE.Rev.1) as a measure of jobs. Individuals aged 18-66 are placed in cells, and weighted by the total population of each cell. Because many cells are empty, two filters are applied to the data. I first drop observations for which information on the job variable is missing. Second, I also drop Melilla and Ceuta region due to no accurate information, reducing the total number of jobs from 276 to 226 jobs.

In the next step, I compute jobs' real hourly wage by taking the ratio of the gross annual salary to the total number of hours actually worked. The salary figure includes extraordinary payments. I then rank jobs according to their mean wage in the first year. $^{24}$

In the last step, I represent graphically the evolution of jobs in terms of their wages where there are three possibilities of representation: the actual point of jobs where I plot the percent change in employment share against the (log) mean wage. In the second case, I display smoothing regressions rather than the actual data point. In the last case, I define the wage quintiles.

\section{Appendix D: Figures}

In Figs. 4, 5, and 6 I establish three time periods due to the reclassifications at the occupation and activity level. Table 13 presents the period, the occupation, the sector and the main earning database (Figs. 7, 8).

24 The shape of the graph does not change if median average are used for determining job quality. 

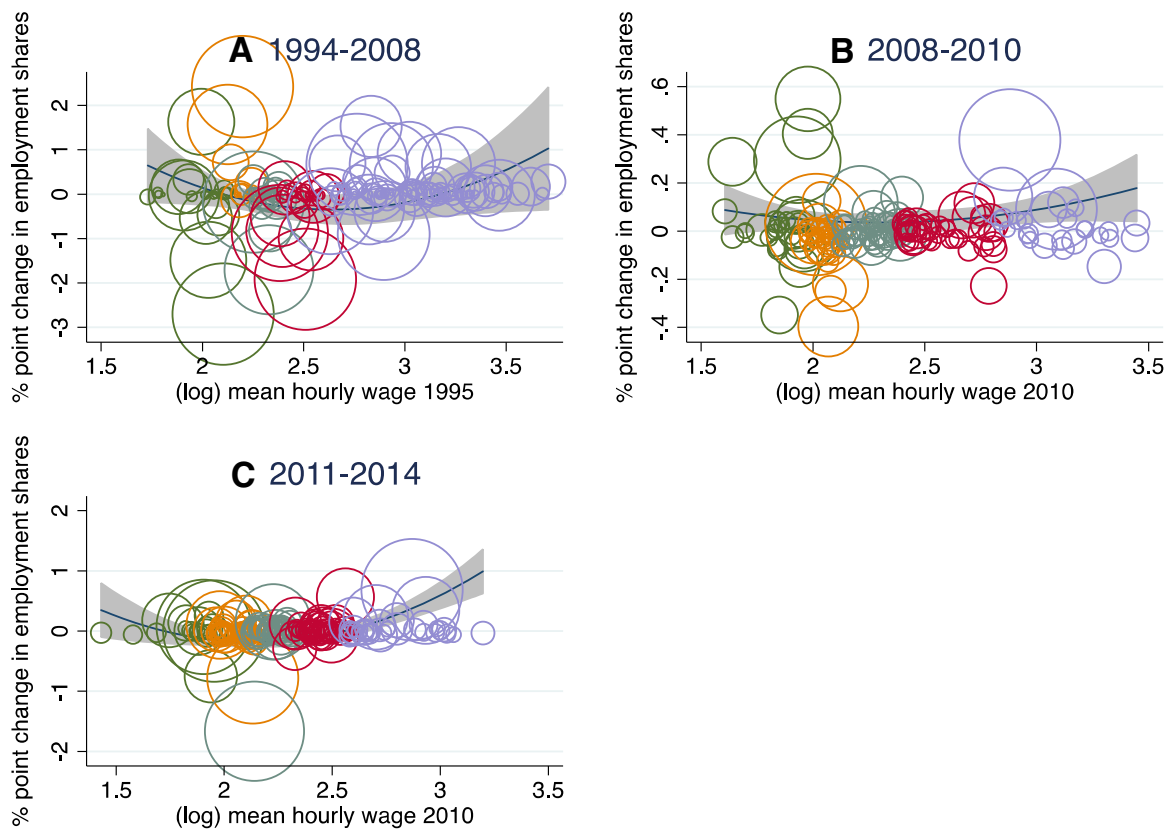

Fig. 4 Employment shares growth in Spain by mean hourly wage in three different periods: 1994-2008, 2008-2010, and 2010-2014. Notes scatter plot and quadratic prediction curve. The dimension of each circle corresponds to the number of observations within each occupation in 1994 (a), in 2008 (b), and in 2011 (c); the grey area shows 95\% confidence interval. Employment shares are measured in terms of workers. Colours represent the quintile of each job (green, first quintile; yellow, second quintile, grey, third quintile; red, fourth quintile; and violet, fifth quintile). Sources author's analysis from the Spanish Labour Force Survey (1994, 2008, 2011, 2014), and the Structure of Earnings Survey (1995, 2010) (color figure online) 

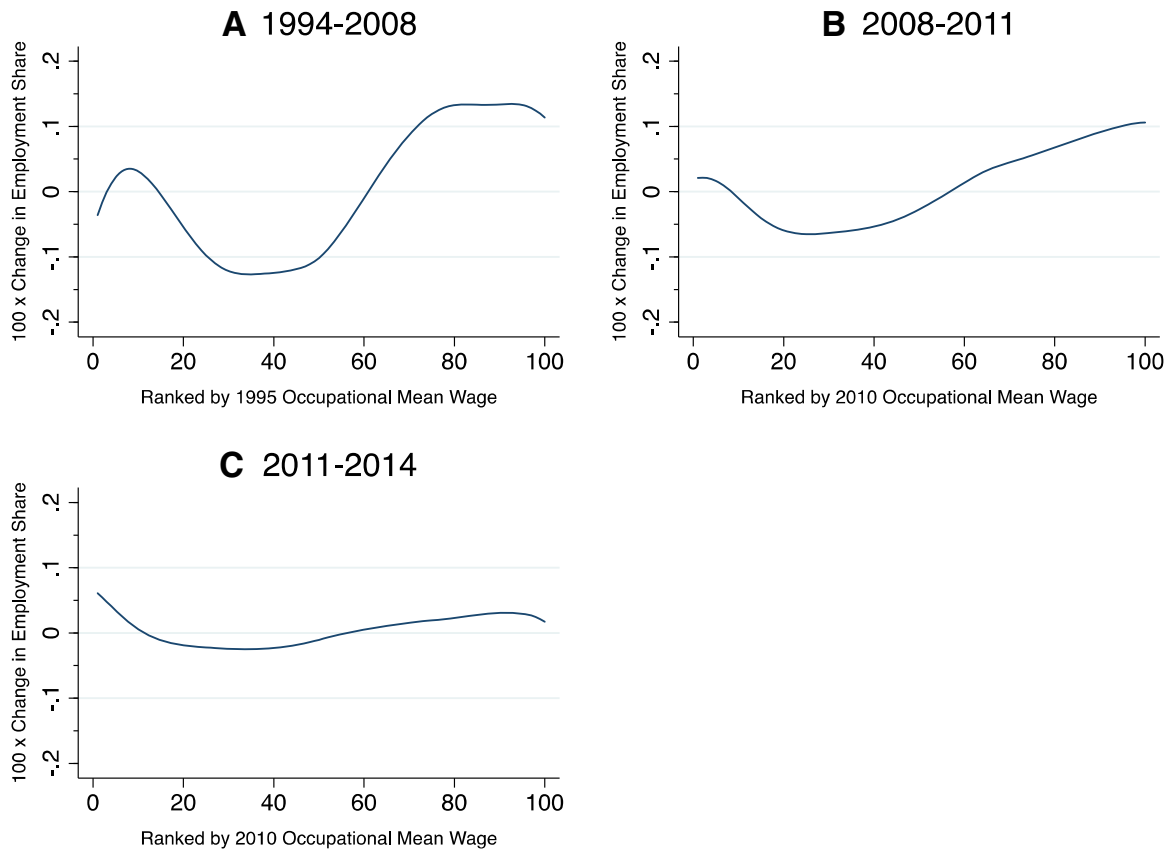

Fig. 5 Smoothed changes in Employment by wage percentile in three different periods: 1994-2008, 2008-2010, and 2010-2014. Notes the figure plots log changes in employment share by 1995 and 2010 job skill percentile rank using a locally weighted smoothing regression (bandwidth 0.75 with 100 observations), where skill percentiles are measured as the employment-weighted percentile rank of a job's mean log wage in the 2002 ESS (a) and the 2010 ESS (b, c). Sources author's analysis from the Spanish Labour Force Survey (1994, 2008, 2011, 2014), and the Structure of Earnings Survey (1995, 2010) 
A $1994-2008$

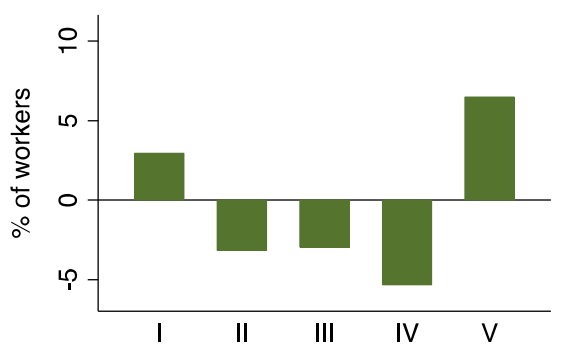

C $2011-2014$

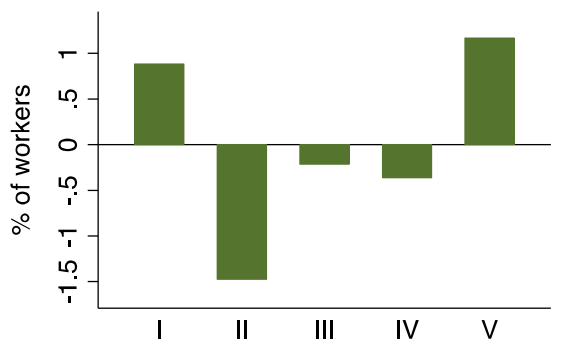

B $2008-2010$

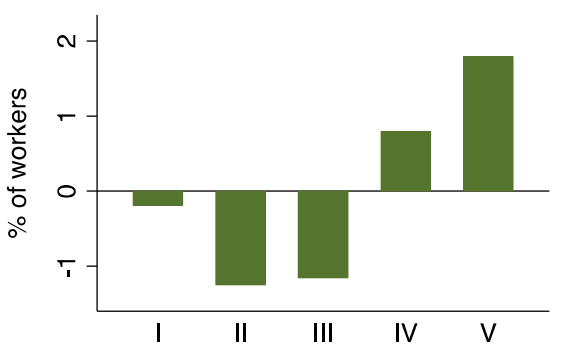

Fig. 6 Relative net employment change $(1994,2014)$ in three different periods: 1994-2008, 2008-2010, and 2010-2014. Notes jobs wage quintiles are based on two-digit occupation and one-digit industry and on mean wages in 2002. It shows the relative net employment change quintiles (in percentage points). a Is based on mean wage in 1995, b, c based on mean wage in 2010. Sources author's analysis from the Spanish Labour Force Survey (1994, 2008, 2011, 2014), and the Structure of Earnings Survey $(1995,2010)$

Table 13 Period of analysis, main classifications and databases to be used

\begin{tabular}{llll}
\hline Period & Occupation & Sector of activity & Source of jobs rank \\
\hline $1994-2008$ & ISCO-88 & Nace.Rev.1 & 2002 EES \\
$2008-2010$ & ISCO-88 & Nace.Rev.2 & 2010 ESS \\
$2010-2014$ & ISCO-08 & Nace.Rev.2 & 2010 ESS \\
\hline
\end{tabular}




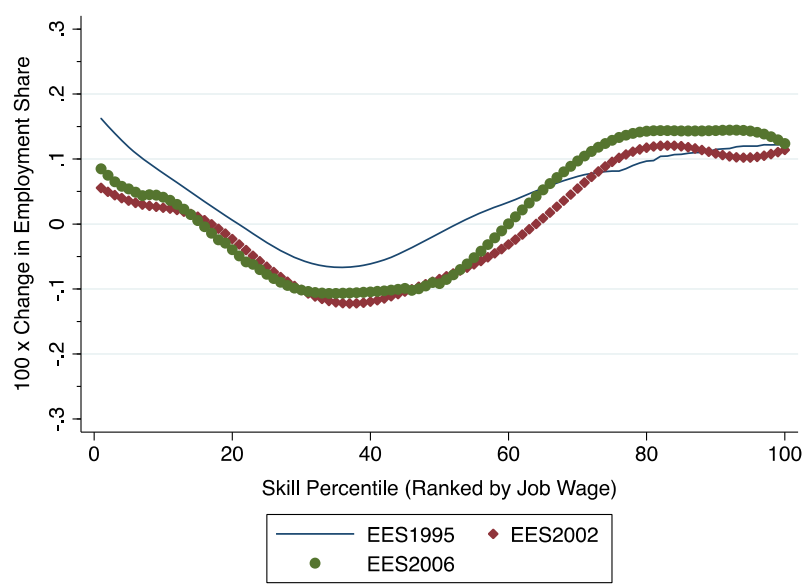

Fig. 7 Smoothed changes in employment in Spain (1994-2014), being jobs ranked in 1995, 2002 and 2006 by EES. Notes the figure plots a locally weighted non-parametric smoothing regression (bandwidth 0.75 with 100 observations). The jobs are defined at two-digit ISCO level and at one-digit NACE Rev.1 level. For the period 1994-2008, jobs are ranked by the EES 1995, EES 2002, and EES2006 media wage. Sources author's analysis from the Spanish Labour Force Survey (1994, 2014), Earnings Structure Survey (1995, 2002, 2006)

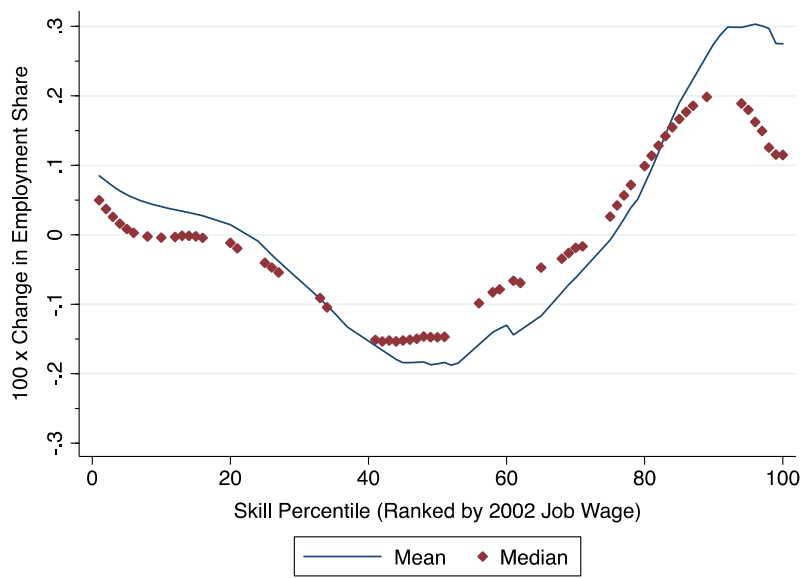

Fig. 8 Smoothed changes in employment in Spain (1994-2008), jobs are ranked by 1995 mean and median wage percentile. Notes the figure plots a locally weighted non-parametric smoothing regression (bandwidth 0.75 with 100 observations). The jobs are defined at two-digit ISCO-88 level and at one-digit NACE.Rev.1 level. For the period 1994-2008, jobs are ranked by the 2002 ESS mean wage (blue line) and 2002 ESS median wage (red line). Sources author's analysis from the Spanish Labour Force Survey (1994, 2014), Earnings Structure Survey (2002) (color figure online)

\section{Appendix E: Variables construction}

Wages My wage variable (hwage) is the gross hourly pay. For all the cases hwage was computed as gross usual weekly pay divided by usual hours and minutes worked per week, including usual overtime. Wages are measured in euro. I trim my data such that hourly wages lower than 1 and higher than 100 are excluded. 
Occupations I classify occupations according to the International Standard Classification of Occupations (ISCO-88). Occupations were originally classified according to the National Classification of Occupations (CNO-94). Codes are manually matched on the basis of the guidelines distributed by the Occupational Information Unit of the Office for National Statistics. This harmonisation allows researchers to compare occupations over time to make our results strictly comparable to other papers.

Industry I classify industry according to the Statistical Classification of Economic Activities in the European Commission (NACE.Rev.1.1). Industry codes were originally classifies according to the National Classification of Economic Activities (CNAE-93). Codes are manually matched on the basis of the guidelines distributed by EUROSTAT. This harmonisation allows researchers to compare occupations over time to make our results strictly comparable to other papers. NACE.Rev.1 defines five levels of aggregation, consisting of 17 one-letter sections, 31 two-letter sub-sections, 60 twodigit main groups, 222 three-digit groups, and 513 four-digit sub-groups. NACE.Rev.1 was in turn based on the International Standard Industrial Classification of All Economic Activities (ISIC) Rev 3, published by the United Nations.

Education My education variable distinguishes four groups of workers: elementary, basic, medium, and high educated (skilled). In the Spanish Labour Force Survey I exploit the variable (estud) which indicates the highest qualification held by the interviewer. Both educational and vocational qualification levels are available in the list provided to respondents. The usual ISCED division into low, medium and high is then adopted where low is equivalent to ISCED 0-2 (i.e. primary and lower secondary education), medium is given by ISCED 3-4 (i.e. upper secondary and post-secondary non-tertiary education) and high is ISCED 5-7 (i.e. tertiary education). The derived categorical variable for education takes value of 1 for low educated, 2 for medium and 3 for high.

Computer use I create a variable that capture computer use. In the EWCS I use the question: "Does your main job involve... working with computer, laptops, etc.? The variable ranges from 1 "all of the time" to 7 "never" ("almost all of the time", "around $3 / 4$ of the time", "around $1 / 2$ of the time", "around $1 / 4$ of the time", and "almost never" correspond to middle answers).

\section{References}

Acemoglu D, Autor D (2011) Skills, tasks and technologies: implications for employment and earnings. In: Ashenfelter O, Card DE (eds) The handbook of labour economics, vol 4, chapter 12. Elsevier, Amsterdam, pp 1043-1171

Adermon A, Gustavsson M (2015) Job polarization and task-biased technological change: evidence from Sweden, 1975-2005. Scand J Econ 117(3):878-917

Anghel B, De la Rica S, Lacuesta A (2014) The impact of the great recession on employment polarization in Spain. SERIEs 5(2-3):143-171

Antonczyk D, DeLeire T, Fitzenberger B (2010) Polarization and rising wage inequality: comparing the US and Germany. Technical report, IZA discussion paper no. 4842

Autor D, Dorn D (2009) This job is "getting old": measuring changes in job opportunities using occupational age structure. Am Econ Rev 99(2):45-51

Autor D, Dorn D (2013) The growth of low-skill service jobs and the polarization of the US labor market. Am Econ Rev 103(5):1553-1597 
Autor D, Handel MJ (2013) Putting tasks to the test: human capital, job tasks, and wages. J Labor Econ 31(S1):S59-S96

Autor D, Katz LF (1999) Changes in the wage structure and earning inequality. In: Ashenfelter O, Card DE (eds) The handbook of labour economics, vol 3A. Elsevier, Amsterdam, pp 1463-1555

Autor D, Levy F, Murnane RJ (2003) The skill content of recent technological change: an empirical exploration. Q J Econ 118(4):1279-1333

Autor D, Katz LF, Kearney MS (2006) The polarization of the US labor market. Technical report, National Bureau of Economic Research. Discussion paper no. 11986

Blinder AS (2009) How many US jobs might be offshorable? World Econ 10(2):41-78

Cortes M (2016) Where have the middle-wage workers gone? A study of polarization using panel data. J Labor Econ 34(1):63-105

Dustmann C, Ludsteck J, Schönberg U (2009) Revisiting the German wage structure. Q J Econ 124(2):843-881

Eurofound (2015) Upgrading or polarisation? Long-term and global shifts in the employment structure: European Jobs Monitor 2015. Publications Office of the European Union, Luxembourg

Fernández-Macías E (2012) Job polarization in Europe? Changes in the employment structure and job quality, 1995-2007. Work Occup 39(2):157-182

Goos M, Manning A (2007) Lousy and lovely jobs: the rising polarization of work in Britain. Rev Econ Stat 89(1):118-133

Goos M, Manning A, Salomons A (2009) Job polarization in Europe. Am Econ Rev Pap Proc 99(2):58-63

Goos M, Manning A, Salomons A (2014) Explaining job polarization: routine-biased technological change and offshoring. Am Econ Rev 104(8):2509-2526

Green F (2012) Employee involvement, technology and evolution in job skills: a task-based analysis. Ind Labor Relat Rev 65(1):36-67

Kampelmann S, Rycx F (2011) Task-biased changes of employment and remuneration: the case of occupations. Technical report, IZA discussion paper no. 5470

Lewandowski P, Keister R, Hardy W, Gorka S (2017) Routine and ageing? The intergenerational divide in the deroutinisation of jobs in Europe. Technical report, IZA discussion paper no. 10732

Massari R, Naticchioni P, Ragusa G (2014) Unconditional and conditional wage polarization in Europe. Technical report, IZA discussion paper no. 8465

Michaels G, Natraj A, Van Reenen J (2014) Has ICT polarized skill demand? Evidence from eleven countries over twenty-five years. Rev Econ Stat 96(1):60-77

Mokyr J, Vickers C, Ziebarth NL (2015) The history of technological anxiety and the future of economic growth: is this time different? J Econ Perspect 29(3):31-50

Oesch D, Rodríguez-Menés J (2011) Upgrading or polarization? Occupational change in Britain, Germany, Spain and Switzerland, 1990-2008. Socioecon Rev 9(3):503-531

Salvatori A (2015) The anatomy of job polarisation in the UK. Technical report, IZA working paper: 9193

Schmidpeter B, Winter-Ebner R (eds) (2016) Polarization and unemployment duration. European Association of Labour Economists (EALE), Maastricht

Sebastian R (ed) (2017) Rethinking job polarisation. European Association of Labour Economists, Maastricht

Spitz-Oener A (2006) Technical change, job tasks, and rising educational demands: looking outside the wage structure. J Labor Econ 24(2):235-270

Wright EO, Dwyer RE (2003) The patterns of job expansions in the USA: a comparison of the 1960s and 1990s. Socioecon Rev 1(3):289-325

Publisher's Note Springer Nature remains neutral with regard to jurisdictional claims in published maps and institutional affiliations. 